\title{
Analisis Penggunaan Konjungsi Dalam Kumpulan Artikel Pada Rubrik Politik Hukum Koran Kompas
}

\author{
Irwan Siagian $^{1)}$, Nur Baiti ${ }^{2)}$, Abdul Harif ${ }^{3)}$ \\ Universitas Indraprasta PGRI \\ email: bnur780@gmail.com
}

\begin{abstract}
Abstrak
Penelitian bertujuan untuk menemukan dan mendeskripsikan fungsi penggunaan konjungsi bahasa Indonesia pada rubrik politik hukum koran Kompas edisi Rabu, 14 Agustus 2019. Metode yang digunakan dalam penelitian adalah metode deskriptif dan bentuk penelitian kualitatif. Data yang diambil dari kumpulan artikel pada rubrik politik hukum yaitu konjungsi. Jika dilihat dari fungsi, konjungsi dapat dibagi menjadi dua kelompok yaitu konjungsi koordinatif dan konjungsi subordinatif. Kemudian, penelitian ini dilakukan dengan menandai konjungsi yang ada di dalam artikel. Berdasarkan hasil analisis bahasa Indonesia pada artikel koran kompas edisi Rabu 14 Agustus 2019 terdapat 68 data konjungsi, terdiri dari konjungsi Koordinatif berjumlah 53 data dan konjungsi subordinatif berjumlah 15 data.
\end{abstract}

Kata Kunci: penggunaan konjungsi, berdasarkan fungsi, artikel.

\section{Abstract}

The research aims to find and describe the functions of the use of Indonesian conjunctions in the Political Law Rubric of Kompas Newspaper Edition Wednesday, August 14, 2019. The method used in this research is descriptive method and qualitative research form. Data taken from a collection of articles in the rubric of legal politics, namely conjunctions. When viewed from a function, conjunctions can be divided into two groups namely coordinative conjunctions, and subordinative conjunctions. Then, this research was conducted by marking the conjunctions in the article. Based on the results of the Indonesian language analysis in the Kompas newspaper article Wednesday, August 14, 2019, there were 68 data conjunctions, consisting of 53 coordinate conjunctions and 15 subordinative conjunctions.

Keywords: the use of conjunctions, based on functions, articles.

\section{PENDAHULUAN}

Konjungsi bahasa Indonesia berdasarkan fungsi terdiri dari Konjungsi koordinatif dan konjungsi Subordinatif. Konjungsi Koordinatif yang berarti konjungsi yang menghubungkan dua konstituen atau lebih yang kedudukanya sederajat. Sedangkan Subordinatif berarti konjungsi yang menghubungkan dua kontituen dengan kedudukan yang tidak sederajat. Jika para pembaca telah memahami penggunaan konjungsi bahasa Indonesia yang terkandung dalam sebuah wacana khususnya artikel, maka pembaca akan lebih mudah memahami apa yang sebenarnya akan disampaikan oleh penulis.

Menurut Kridalaksana (2007: 102), "Konjungsi adalah kategori yang berfungsi untuk meluaskan satuan yang lain dalam kontruksi hipotaktik, dan selalu menghubungkan dua satuan lain atau lebih dalam kontruksi. Konjungsi menghubungkan bagian-bagian ujaran yang setataran mapun yang tidak setataran."

Menurut Chaer (2009 : 82), "Konjungsi Koordinatif merupakan kelas kata konjungsi yang menggabungkan dua unsur kalimat yang setara. Konjungsi ini dibedakan pula atas konjungsi yang menghubungkan menyatakan. Kemudian konjungsi koordinatif adalah konjungsi yang menyatakan dua konstituen yang kedudukannya tidak sederajat. Ada konstituen atasan dan ada konstituen bawahan."

Menurut Finoza (2013: 103), "Kata sambung atau konjungsi adalah kata tugas yang berfungsi menghubungkan dua kata atau kalimat. Mengingat peranannya sebagai kata penghuhubung, kata sambung disebut juga dengan istilah konjungtor." Selanjutnya menurut Alwi (2014: 301), "Konjungtor yang juga dinamakan kata sambung, adalah kata 
tugas yang menghubungkan dua satuan bahasa yang sederajat: kata dengan kata, frasa dengan frasa, klausa dengan klausa."

Dari sekian definisi dari para pakar diatas dapat disimpulkan bahwa konjungsi, konjungtor, ataupun kata hubung merupakan sebuah partikel atau satuan dari sintaksis yang berfungsi untuk menghubungkan kata dengan kata, klausa dengan klausa, kalimat dengan kalimat, agar membentuk sebuah paragraf yang padu.

Peneliti tertarik untuk mengangkat penelitian kebahasaan tentang penggunaan konjungsi koordinatif dan subordinatif bahasa Indonesia pada Rubrik Politik Hukum Koran Kompas Edisi Rabu 14 Agustus 2019. Keunggulan penelitian yang dilakukan adalah memilih konjungsi sebagai bahasan yang akan diteliti diantaranya (1) konjungsi merupakan kajian bahasa yang mudah dipahami; (2) Konjungsi berdasarkan fungsi memiliki bagian yaitu konjungsi koordinatif dan subordinatif. (3) Konjungsi selalu digunakan dalam tulisantulisan, baik dalam karya tulis, maupun di media-media masa seperti koran.

Kelebihan memilih surat kabar sebagai bahan atau objek yang akan diteliti adalah: (1) Kompas merupakan surat kabar yang banyak diminati orang sebagai bahan bacaan, dikarenakan beritanya menarik dan mengungkapkan isi berita secara jelas; (2) Bahasa yang digunakan dalam kompas mudah dipahami karena bahasa yang digunakan bahasa Indonesia, karena ada beberapa Koran yang menggunakan bahasa daerah; dan (3) Sesuai dengan konjungsi yang akan diteliti. Berdasarkan rumusan masalah di atas, terdapat tujuan yang ingin dicapai dalam penelitian ini yaitu penggunaan konjungsi koordinatif dan subordinatif dalam artikel Koran Kompas Edisi Rabu 14 Agustus 2019.

\section{METODE PENELITIAN}

Metode yang digunakan dalam penelitian ini adalah metode deskriptif. Metode deskriptif adalah data yang dikumpulkan berupa katakata, gambar dan bukan angka-angka. Bentuk penelitian adalah kualitatif. Bentuk penelitian kualitatif merupakan penelitian yang mementingkan proses daripada hasil dan analisisnya berupa kata-kata tertulis bukan berupa statistik atau angka.Sumber data yang digunakan dalam penelitian berasal dari Koran Kompas Edisi Rabu 14 Agustus 2019. Data dalam penelitian berupa kata-kata tertulis yang terdiri konjungsi koordinatif dan subordinatif. Teknik pengumpulan data yang digunakan dalam penelitian ini teknik analisis isi. Menurut Soewardji (2012:31), "Dalam metode analisis isi unit analisisnya adalah isi media cetak seperti berita, features, artikel, kolom, dan sebagainya ataupun media elektronik seperti program berita, pendidikan, atau hiburan dan yang lain-lain.”

\section{HASIL DAN PEMBAHASAN}

Berdasarkan hasil penelitian tentang penggunaan konjungsi bahasa Indonesia yang terdapat pada koran Kompas edisi Rabu 14 Agustus 2019 yang terdiri dari konjungsi koordinatif dan subordinatif.

\section{a. Konjungsi Koordinatif}

Data (1) Dari ulah kelompok kriminal bersenjata atau KKB.

Kutipan kalimat berita pada data (1) terlihat bahwa kata "atau" terletak diantara dua buah klausa tersebut memiliki fungsi sebagai pemilihan atau konjungsi koordinatif.

Data (2) Korban meninggal sebanyak 23 warga sipil dan 16 personil TNI/ Polri

Berdasarkan kutipan kalimat berita pada data (2) terlihat bahwa kata "dan" memiliki fungsi sebagai penjumlahan atau konjungsi koordinatif.

Data (3) Heidar pun turun, tetapi tiba-tiba 10 orang tak dikenal muncul dari semaksemak.

Berdasarkan kutipan kalimat berita pada data (3) terlihat bahwa kata "tetapi" memiliki fungsi sebagai pertentangan atau konjungsi koordinatif. 
Data (4) Untuk menangkap anggota kelompok itu namun, pihaknya mengakui bahwa medan luas menjadi kendala.

Berdasarkan kutipan kalimat berita pada data (4) terlihat bahwa kata "namun" terletak diantara dua buahmemiliki fungsi sebagai pertentangan atau konjungsi koordinatif.

Data (5) Selain itu, banyak juga yang merasa trauma dengan sejarah kekerasan di papua sejak 1997.

Berdasarkan kutipan kalimat berita pada data (5) terlihat bahwa kata "dengan" terletak diantara dua buahmemiliki fungsi sebagai penyimpulan atau konjungsi koordinatif.

Data (6) Bekas direktur utama PT Sandipala Arthaputra, Yakni Paulus Tannos.

Berdasarkan kutipan kalimat berita pada data (6) terlihat bahwa kata "yakni" terletak diantara dua buah memiliki fungsi sebagai penyamaan atau konjungsi koordinatif.

Data (7) DPR lebih banyak diisi oleh caleg pertahanan, sedangkan DPD didominasi caleg nonpertahanan.

Berdasarkan kutipan kalimat berita pada data (7) terlihat bahwa kata "sedangkan" terletak diantara dua buahmemiliki fungsi sebagai pertentangan atau konjungsi koordinatif.

Data (8) Apabila kemudian para caleg terpilih itu tidak mampu menunjukan komptensinya tak akan ada perubahan yang signifikan.

Berdasarkan kutipan kalimat berita pada data (8) terlihat bahwa kata "kemudian" terletak diantara dua buah memiliki fungsi sebagai pengurutan atau konjungsi koordinatif.

Hasil analisis Konjungsi koordinatif yang terdapat dalam Koran Kompas Edisi Rabu 14 Agustus 2019 maka dapat disimpulkan bahwa adapun temuan konjungsi koordinatif diantaranya atau, dan, tetapi, namun, dengan, yakni, sedangkan, adalah dan kemudian yang secara keseluruhan konjungsi koordinatif berjumlah 53 data.

\section{b. Konjungsi Subordinatif}

Konjungsi Subordinatif yang terdapat dalam Koran Kompas Edisi Rabu 14 Agustus 2019 adalah karena, sehingga, sebelum, mesipun, seperti, sebagai dan agar.

Data (9) Masuknya sosok sosok nonpertahanan di kedua lembaga tinggi negara itu dinilai belum dijanjikan perubahan karena sebagian dari caleg nonpertahanan itu masih terkait dengan jejaring politik kekerabatan.

Berdasarkan kutipan kalimat berita pada data (9) terlihat bahwa kata "karena" memiliki fungsi sebagai penyebaban atau konjungsi koordinatif.

Data (10) Substansi rancangan undangundang keamanan dan ketahanan siber yang merupakan usulan inisiatif DPR dinilai masih problematik sehingga berpotensi menyebabkan kekacauan jika terburu-buru disahkan September 2019.

Berdasarkan kutipan kalimat berita pada data (10) terlihat bahwa kata "sehingga" memiliki fungsi sebagai pengakibatan atau konjungsi subordinatif.

Data (11) Ketua lembaga riset keamanan Cyber dan komunikasi pratama persadha mengatakan, sebelum RUU KKS dibahas, setiap pemangku kepentingan perlu duduk bersama.

Berdasarkan kutipan kalimat berita pada data (11) terlihat bahwa kata "sebelum" memiliki fungsi sebagai kesewaktuan atau konjungsi subordinatif.

Data (12) Setiap pemangku kepentingan perlu duduk bersama. Meskipun urgensi RUU KKS tinggi, mengingat saat ini ada kekosongan hokum.

Berdasarkan kutipan kalimat berita pada data (12) terlihat bahwa kata "meskipun" memiliki fungsi sebagai penyungguhan atau konjungsi suordinatif.

Data (13) Kasus yang merugikan negara hingga Rp.2,3 triliun ini telah menyeret banyak pihak, seperti pegawai kementrian dalam negeri Irman dan Sugiharto.

Berdasarkan kutipan kalimat berita pada data (13) terlihat bahwa kata "seperti" 
memiliki fungsi sebagai perbandingan atau konjungsi suordinatif.

Data (14) Pemimimpin konsorsium disepakati dari BUMN yaitu, PNRI, agar mudah diatur.

Berdasarkan kutipan kalimat berita pada data (14) terlihat bahwa kata "agar" memiliki fungsi sebagai tujuan atau konjungsi suordinatif.

Data (15) karena dipersiapkan sebagai konsorsium yang akan memenangkan lelang pekerjaan penerapan KTP elektronik.

Berdasarkan kutipan kalimat berita pada data (15) terlihat bahwa kata "sebagai" memiliki fungsi sebagai perbandingan atau konjungsi subordinatif.

Berdasarkan hasil analisis Konjungsi Subordinatif yang terdapat dalam koran Kompas edisi Rabu 14 Agustus 2019 maka dapat disimpulkan bahwa adapun temuan konjungsi Subordinatif diantaranya karena, sehingga, sebelum, meskipun, seperti, sebagai dan agar yang secara keseluruhan konjungsi Subordinatif berjumlah 15 data.

\section{KESIMPULAN}

Berdasarkan analisis penggunaan konjungsi bahasa Indonesia pada koran Kompas Edisi Rabu 14 Agustus 2019 terdapat bebrapa data tentang konjungsi. Adapun data keseluruhan berjumlah 68 data, yang terdiri dari konjungsi koordinatif yang terkumpul berjumlah 53 data ( atau, dan, tetapi, namun, dengan, yakni, sedangkan, adalah dan kemudian). Sedangkan konjungsi Subordinatif yang terkumpul berjumlah 15 data yang terdiri dari penggunaan konjungsi subordinatif (karena, sehingga, sebelum, mesipun, seperti, sebagai dan agar).

\section{DAFTAR PUSTAKA}

Alwi, H, dkk. (2014). Tata bahasa baku bahasa Indonesia. Jakarta : Balai Pustaka.

Chaer, A. (2009). Sintaksis bahasa Indonesia. Jakarta: Rineka Cipta.
Finoza, L. (2013). Komposisi bahasa Indonesia untuk mahasiswa nonjurusan bahasa. Jakarta: Diksi Insan Mulia.

Kridalaksana, H. (2007). Kelas kata dalam bahasa Indonesia. Jakarta: Gramedia Pustaka Utama.

Soewadji, J. (2012). Pengantar metodologi penelitian. Jakarta: Mitra Wacana Media. 